\title{
EFL Learners' Perspectives on the use of Smartphones in Higher Education Settings in Slovakia
}

\author{
Rastislav Metruk \\ University of Žilina, Slovakia \\ rastislav.metruk@fhv.uniza.sk \\ DOI: 10.34190/JEL.18.6.006
}

\begin{abstract}
MALL (Mobile assisted language learning) affords new opportunities for EFL (English as a foreign language) learners and teachers. Research on MALL is still in its infancy in Slovakia, and this paper attempts to fill in this gap by examining students' perception and attitudes towards the use of smartphones for the purposes of learning and practicing English. The target population of this study constituted of the Slovak university EFL learners whose major was Teacher Training of English Language and Literature $(n=77)$ at a Slovak university. The research method employed to achieve the objectives of this study was a 5-point Likert scale questionnaire, comprising of two sets of statements: general and out-ofthe-classroom statements with a total of 29 items. The research results for both sets of statements imply that the participants display moderately positive attitudes towards smartphones in the context of EFL learning. However, the findings also reveal some issues surrounding the perception and potential use of smartphones such as the inability to plan students' language learning appropriately and effectively, general underuse of smartphone apps, or problems related to practicing speaking skills. The results further suggest the immediate need to develop and enhance the awareness of smartphones and their potential in the process of teaching and learning English so that the EFL learners can utilize considerable opportunities these smart devices offer. Finally, the limitations of this study are recognized, and it is emphasized that conducting further research in this area is urgently needed.
\end{abstract}

Keywords: EFL learner, mobile learning, smartphone and language learning, attitudes and perceptions, process of learning English

\section{Introduction}

Modern technologies have caused changes in every sphere of human activity and it is also education which has served as a focus of technological intervention for some time (Straková and Cimermanová, 2018). "Educational practices are constantly adjusting to technological advances, in order to improve their effectiveness in delivering knowledge and preparing students for the challenges of modern digital society" (Rovithis, et al., 2019, p.144), which offers a possibility of enhancing educational practices and approaches.

The modern-day English language is linked with advancements in many fields (e.g. tourism, trade, science, etc.) including innovations in technology (Kandasamy and Habil, 2018; Namaziandost, Shatalebi and Nasri, 2019). Mobile devices, which occupy a powerful role with regard to the implementation of technology into the teaching and learning process (Klímová, 2018), have become indispensable for modern society as contemporary issues call for effective communication in foreign languages (Nikolajová-Kupferschmidtová, Štubňa and Kučmová-Lenzi, 2018; Štubňa, 2019), including English.

However, it should be also noted that in order to recognize and obtain the benefits of implementing technology into the teaching and learning process, teachers ought to be able to use technology appropriately and effectively within their practice. The increasing trend in the shift from the use of computers to the use of smartphones merits attention of instructors and researchers, and numerous aspects concerning the implementation of mobile devices into teaching and learning English (extent, manner, frequency, etc.) ought to be investigated and elucidated. This paper attempts to contribute the attitudes of Slovak EFL learners towards smartphones to the research agenda on smartphones in the context of English language learning.

\section{Research background}

The smartphone is regarded as a handy and multipurpose mobile device that assists people to perform their daily and professional activities and duties (Almunawar, et al.,2015; Anshari, et. al., 2019). However, finding a satisfactory definition of the word smartphone in the literature is a formidable task. "Despite the lack of a standard definition, the term smartphone generally refers to a mobile phone offering some computer-like functionalities, including Internet access" (Kim, Chun and Lee, 2014). These smart devices include sophisticated hardware along with the clearly identifiable operating system (e.g. Android, Blackberry, Apple's iOS, Windows Phone, etc). 
The operating system allows the installation of the third-party applications (apps) from application markets such as Android Market, BlackBerry App World, or App Store (Theoharidou, Mylonas and Gritzalis, 2012). This is also the reason why smartphones are technologically superior to standard mobile phones (Barrs, 2011); EFL learners are able to install a high number of English language learning apps (based on their personal preference), and use them whenever and wherever they want. This can be regarded as a considerable benefit which regular mobile phones were not able to provide.

Smartphones are built on an operating system, and they have more advanced connectivity and computing capability when compared to standard phones, which means that they can be regarded as mini computers that are regular cell phones at the same time (Yaman, Şenel and Yeşilel, 2015). Thus, smartphone users have plenty of opportunity to perform a high number of tasks of various types using these smart devices.

The number of people owning a smartphone has increased significantly in recent years. There are over three billion smartphone users in the world today, and the number is forecast to further grow by several hundred million in years to come (Statista, 2019). Therefore, smartphones are likely to influence the teaching and learning process in the future to an even greater degree (they are already exerting a powerful impact on educational practices worldwide), and the question arises as to how smartphones can be used within the educational process, and what the attitudes of EFL learners towards these smart devices are.

Smartphones, which demonstrate tremendous potential for becoming a useful gadget in EFL classes, may help students become more autonomous, also by offering independent access to various materials via the Internet (Yaman, Şenel and Yeşilel, 2015). The importance of smartphones is also acknowledged by Alzubi and Singh (2017), who indicate that more control over the learning process can be achieved by learners, and they are able to connect to other learners. "Today, the smartphone is the latest invention in mobile technology which has gained popularity and attention of academia" (Abdullah, Tajuddin and Soon, 2019, p. 61). The significance of smartphones is undeniable, but one must take both advantages and disadvantages into account.

One of the key advantages of smartphones is that its users can be connected to the Internet anytime and anywhere, hence the possibility for working outside offices, studying outside schools, cooperating on home assignments, projects, or seminar papers at students' home.

Another considerable benefit results from the advantages English language learning apps offer (a substantial number of applications can be installed into smartphones). According to Rosell-Aguliar (2014), the likelihood that one application will offer all the solutions students need regarding language learning is rather low. This can be, however, solved by installing further apps for various learning purposes such as developing vocabulary, honing listening skills, or practicing reading subskills. "This is the best thing that apps can bring: a portable solution to every learning style which can suit different language learning skill requirements: grammar, vocabulary, reading, listening, writing or speaking" (Rosell-Aguilar, 2014). EFL learners can actually practice all the language systems and skills by choosing the appropriate application. Hossain (2018) mentions the following benefits students can experience with English language learning apps:

- $\quad$ practice any item of the language anytime anywhere;

- the smartphones and the apps are portable;

- the learners don't have to carry books, pen and paper;

- they can take tests on the different skills of the target language;

- they can share their proficiency with their friends through the same device;

- they can practice the four skills of the target language on the same device;

- $\quad$ on the apps, they can have lessons and tips on the different skills;

- they can have knowledge and fun together;

- they can be technologically advanced and linguistically benefited simultaneously;

- they can get the apps for free;

- apps can accompany them 24/7 like an expert teacher on the target language.

Therefore, EFL learners have a possibility to choose when, where, how they can work on their language systems and skills according to their personal needs and weaknesses they suffer from concerning particular aspects of the English language. Furthermore, they can do this without books, pen or paper, with a chance of sharing their success with their peers, possibly having fun and acquiring knowledge at the same time. 
On the other hand, there are also some drawbacks that need to be overcome by both EFL teachers and learners. Since the app developers are working $24 / 7$, the number of applications on the market is enormous, and one might experience difficulties in choosing the appropriate ones. Therefore, finding the proper apps within the vast number of applications requires time. Moreover, the functionality of some apps may be questionable at times; some of them may have bugs that need to be eventually eliminated by the developers.

\section{Literature review}

Attitudes and perceptions of EFL learners towards smartphones in the EFL classroom have been explored in numerous studies with interesting outcomes as illustrated in the following paragraphs.

Abdullah, Tajuddin and Soon (2019) explored how Mandarin students perceive smartphone applications as well as its usability, effectiveness, and satisfaction. The findings revealed that learning Mandarin by means of smartphone applications influenced their language performance, task accomplishment, and personal study in a positive way. Moreover, learners were engaging, satisfied, and willing to proceed with using smartphones in their study.

Another study by Tayan (2017) attempted to examine thoughts, reflections, attitudes, and perceptions of mobile device/smartphone adoption in order to facilitate and support the contemporary classroom approach to EFL learning. The findings of the study, based on the student questionnaire and teacher interviews, generally highlight positive attitudes and receptiveness towards the implementation of mobile learning. Moreover, the results revealed that learners' autonomy was facilitated, and the students could collaborate to a greater extent within a richer learning environment.

The research results of the study carried out by Sarhandi, Bajnaid and Elyas (2017) demonstrate that students indicated a significant difference in their emotional attitudes towards smartphone activities when compared to the paper-based ones, demonstrating a considerably higher level of task engagement. On the other hand, White and Mills (2014) found out that although learners are increasingly adopting smartphones when it comes to personal usage, they appear to be unwilling to utilise smartphones for the purposes of education, based on the current application use. However, attitudes towards employing smartphones for learning have become more positive within the twelve-month period during which the attitudes towards the use of technology were examined.

Some scholars attempted to examine the notions of motivation and anxiety in relation to learning a foreign language. Several studies (Baluha, Marques and Martins, 2015; Tayan, 2017; Teodorescu, 2015) revealed that learners who use mobile phones or smartphones and their apps seem to be more motivated to learn in the classroom as well as outside the classroom, experiencing a lower level of anxiety (Luo, et. al., 2015). It should be mentioned that anxiety represents one of the key matters within language learning, and several scholars explored anxiety from different standpoints (see, for example, Woods and Scott, 2016 or Machmud, 2018).

In their study Ansarin, et. al, (2017) attempted to investigate the students' attitudes towards smartphones and tablets. The findings revealed that both tablets and smartphones were evaluated positively - increasing students' motivation to study and being a means to develop reading comprehension, spelling, and vocabulary. Nonetheless, the learners' expectations regarding the impact of these devices on students' reading speed, test and quiz preparation as well as comfort and enjoyment were not reached.

Several studies, offering different outcomes, also concentrated on the perception of mobile devices/smartphones by teachers. The research results in the study conducted by Abugohar, Yunus and Rashid (2019) show that most of the participants (teachers) reflect high, inspiring, and positive perceptions of using smartphone apps in teaching speaking. It was also Alzubi (2019) who examined attitudes of EFL teachers to smartphones in the Kingdom of Saudi Arabia. The findings revealed that most of the participants supported the notion of integrating smartphones in the EFL context. Another study conducted by Ozdamli and Uzunboylu (2015) compared teachers' and students' perceptions and abilities regarding m-learning. The authors concluded that both teachers and students are in favour of using m-learning in education; their perceptions are positive, but their adequacy levels concerning m-learning do not seem to be sufficient. Kafyulilo's study (2014) showed that students, pre-service teachers, and college instructors supported the notion of using mobile phones for the purposes of learning, but most of the in-service teachers were against it. 
The above-mentioned studies reveal that apart from positive perceptions of smartphones, there seem to exist some doubts and hindrances concerning their use in the EFL settings. Various issues can be raised when mobile technology platforms are adopted for the purposes of learning such as the price of the device, physical properties (e.g. small screen, small keyboard, limited data storage, limited battery life, etc.), reluctance to use smartphones for learning, learners' distraction, or teachers' willingness and readiness to employ these devices as educational tools (Aljaloud, et. al., 2019; Ismail, et. al., 2013; Metruk, 2019; Metruk, 2020). These are definitely issues that warrant attention of teachers and researchers worldwide and which need to be dealt with and resolved soon.

Margaryan, Littlejohn and Vojt, (2011) explored the extent and nature of university students' use of digital technologies regarding socializing and learning. This study did not produce evidence which would support general assertions that young people adopt radically different learning styles. The attitudes of the students towards learning seem to be influenced by lecturers' teaching approaches. The learners appear to adhere to traditional pedagogies, with minor use of tools that deliver content. "The outcomes suggest that although the calls for transformations in education may be legitimate it would be misleading to ground the arguments for such change in students' shifting patterns of learning and technology use" (Ibid.). Therefore, not all young people necessarily cultivate markedly different learning styles, teaching approaches exerting noticeable impact on learning.

Kim, et. al. (2013) explain that although numerous teachers and instructors already use technology in their classes, they ought to consider modifying existing activities so as to make them more meaningful and practical for language learning when mobile technologies are employed. This demonstrates the importance of using technologies appropriately and effectively - to tailor them for learning purposes, making the tasks and exercises meaningful.

Kukulska-Hulme (2009) draws attention to another related issue. Mobile technology often takes learning outside the classroom, frequently beyond the teacher's reach. This can be viewed as a certain type of threat, and the challenge lies in developing designs that would clearly identify what is best learnt in the classroom, what is best learnt outside, and the ways by which the connections between the two settings would be made. It seems that some harmony needs to be achieved between learning inside and outside the classroom as these two notions are clearly linked.

Ebadi and Bashiri (2018) examined the EFL learners' viewpoints on their experiences with vocabulary learning using a smartphone application. The research results suggest that the learners displayed positive attitudes towards the smartphone app since it influenced their learning in a positive way and provided them with form and meaning-focused instruction. However, the participants were not satisfied with the app's levels and authenticity, which represents one of the issues connected with smartphone applications (this has been discussed earlier).

The research performed by Şad and Göktaş (2014) explored how pre-service teachers perceived m-phones and laptops as mobile learning tools in education. The results suggested that the pre-service teachers' perception of laptops was potentially stronger than that of m-phones. Generally, the attitudes towards the use of laptops were not extremely positive, but significantly more positive than those of $\mathrm{m}$-phones. The research results further indicate that there exists an urgent need to develop and increase the awareness of the m-learning (especially m-learning through $\mathrm{m}$-phones) concept among the participants. Thus, this study also suggests that m-learning is not always perceived positively, and that the positive attitudes need to be somehow developed, also by raising awareness of m-learning.

In the light of the literature review and due to the fact that such research is absent in the Slovak context, this study attempts to verify the previous findings regarding the perception of smartphones in relation to their use in the process of teaching and learning English. Moreover, it is hoped that the outcomes of this paper will provide suggestions and recommendations for further exploration in this field. 


\section{Research methodology}

\subsection{Research design}

The objective of this study is to investigate the attitudes of Slovak university EFL students towards employing smartphones in the EFL settings. The study was conducted in Slovakia using convenience sampling. The subjects were given two sets of statements via the research method questionnaire, which was distributed electronically using the Google Forms survey administration application, and they were asked to choose one of the five options: strongly agree, agree, neutral, disagree, strongly disagree (a Likert scale of 1 [strongly disagree]) to 5 [strongly agree] was adopted). The two sets of statements were comprised of the general statements (10 statements) and outside-the-classroom statements (19 statements). After the data were obtained, they were analysed, interpreted, and conclusions were drawn. The following research questions were formulated:

1. What are the university EFL students' general perceptions and attitudes towards the use of smartphones for the purposes of learning English?

2. What are the university EFL students' perceptions and attitudes towards the use of smartphones for the purposes of learning English outside the EFL classes?

\subsection{Sampling}

The target population was formed by B.A. and M.A. students of the study program Teacher Training of English Language and Literature at a Slovak university - convenience sampling. The total research sample $(n=77)$ comprised of 60 females (77.9\%) and 17 males (22.1\%). They were approximately 22 years of age on average, all of them having Slovak nationality, residing in Slovakia. The year they were studying in at the time of this research is shown in Figure 1.

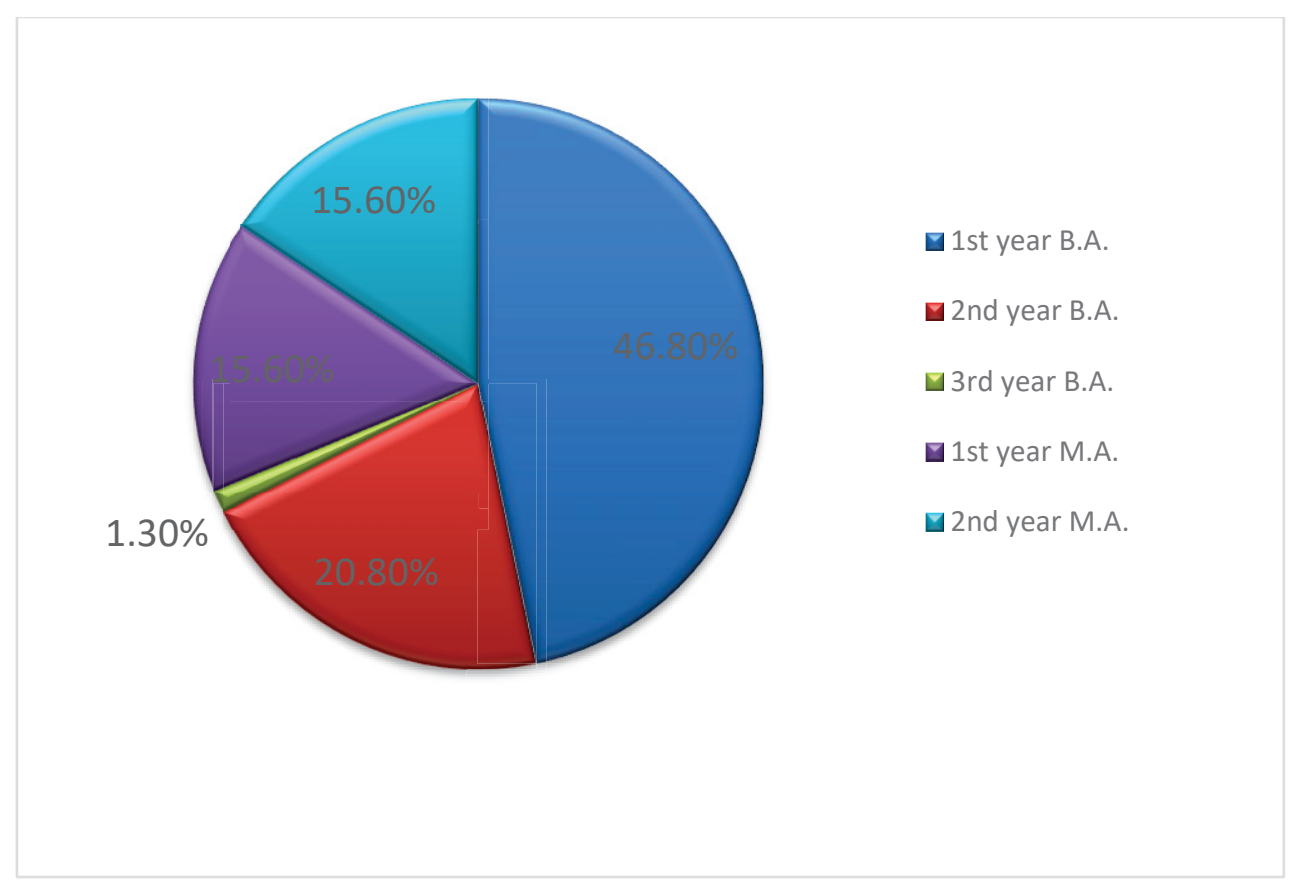

Figure 1: Subjects' year of study

In order to gather more information on the participants, they were asked to reveal which brand of smartphones they use. Figure 2 illustrates their smartphone ownership. Apple, Huawei, and Samsung earned most of the mentions (respectively), followed by Honor, Lenovo, Motorola, Nokia, and LG. Other brands (8) included OnePlus, Allview, Microsoft, Sony, Acer, Bluboo, Gigabyte, and Asus.

Apple, Samsung, and Huawei were prevalent among the research participants, which shows that there are differences not only between the smartphone operating systems, but also within the applications used as apps are developed differently for the two operating systems. The knowledge of smartphone brand enables teachers and researchers to achieve a deeper understanding of attitudes of EFL learners to smartphones in the context of English language learning. 


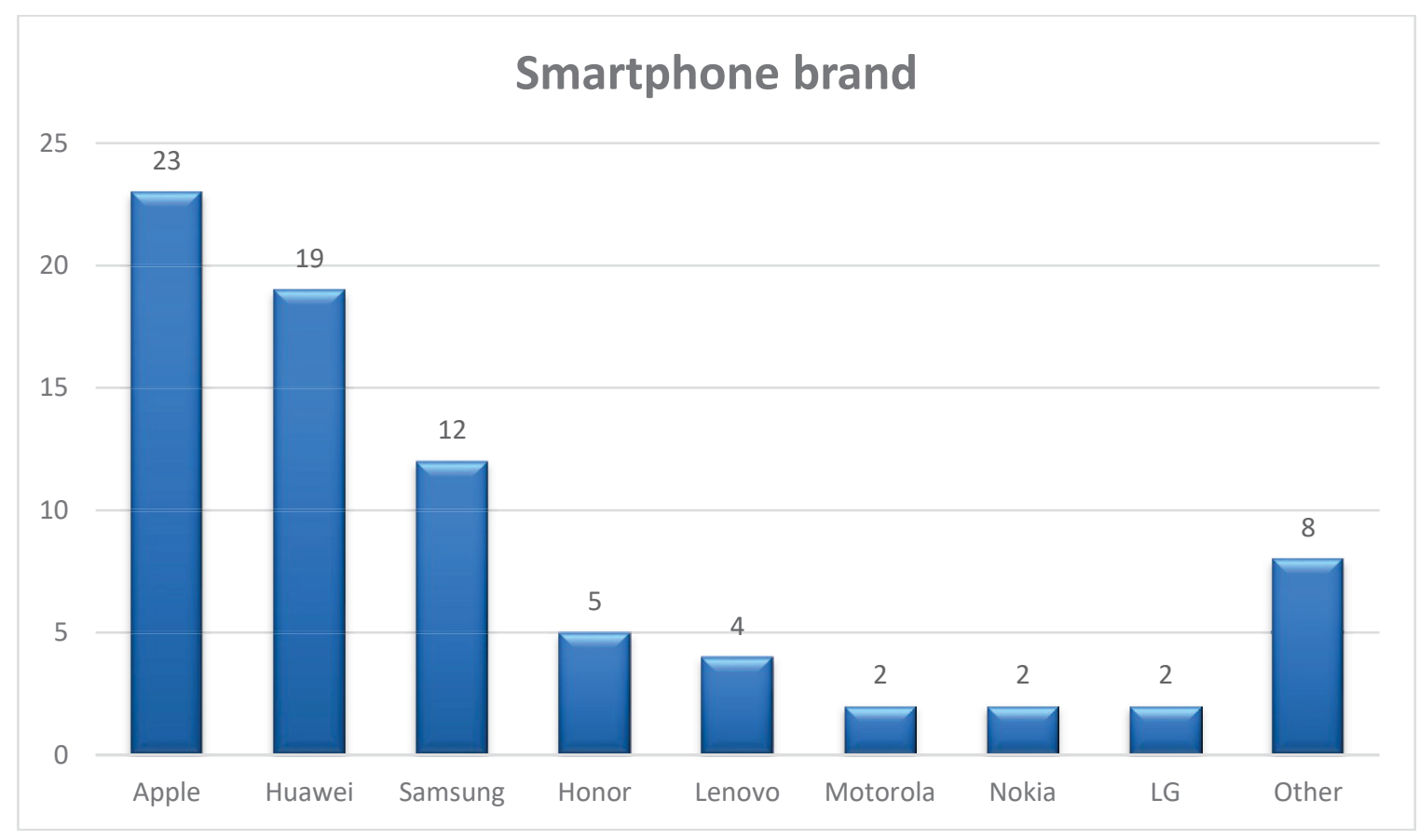

Figure 2: Subjects' Smartphone brand

\subsection{Instrument and data collection procedure}

The data were obtained through a questionnaire that concentrated on the attitudes of Slovak university EFL learners towards smartphones within teaching and learning English as a foreign language. The questionnaire was modified and revised twice employing help of the author's colleagues. The final version of the questionnaire, which was administered through Google Forms, comprised of two sets of statements (the statements were carefully chosen in order to answer the research questions) on the following: general statements (10 items) and outside-the-classroom statements (19 items). In total, there were 29 statements, and the quantitative data were gleaned using a Likert scale of 1 to 5 , where 1 corresponds to a strong disagreement and 5 corresponds to a strong agreement. The participants were informed that their names and places would remain omitted to ensure anonymity. Descriptive statistics of the Likert-based questions were conducted.

\section{Results and discussion}

The findings of this study will offer some new insights regarding the EFL students' perceptions and attitudes towards the use of smartphones for the purposes of learning English.

\subsection{General statements}

The first research question was aimed at analysing the participants' general attitudes towards smartphones. Table 1 shows the students' responses to the general statements. The majority of subjects agree with the statements $1,3,4,8,9$, and 10 , but their level of agreement is lower within the statements $2,5,6$, and 7 .

Overall, it can be concluded most of the students assent to the following. The introduction of smartphones contributes to their language learning process. Learning English using a smartphone represents an innovative and effective way of learning a foreign language, and smartphones, which open up great opportunities for language learners, enable them to practice and enhance their language skills whenever and wherever they want - their learning is independent of time and place, which can be regarded as an asset to the foreign language learning. It should be also noted that the majority of subjects agree that employing smartphones makes them more autonomous and less teacher-dependent, and that these smart devices will form an inseparable part of their language learning process in the future, which emphasizes the significance of smartphones in years to come. These findings support the notions expressed by Alzubi and Singh (2017) or Yaman, Şenel and Yeşilel (2015) who maintain that smartphones hold considerable potential for enhancing the learning process and for making learners less dependent, which allows them to become more autonomous. 
Moreover, they can practice their language systems and skills in an innovative and possibly effective way, which could lead to the enhancement of their language learning process.

Although the overall calculated mean was 3.52, which indicates that the students displayed a reasonably positive attitude towards smartphones in terms of learning English as a foreign language, there still exist issues that need to be addressed and discussed. The research results reveal that the students do not seem to be competent enough to plan their language learning via smartphones carefully and well enough. This appears to correspond with the paper written by Kukulska-Hulme (2009) who touches on the issue of identifying what is best learnt in the classroom and what is best learnt outside the classroom. With the help of their teachers, the learners ought to find a way how to manage and plan their language learning effectively, possibly seeking some harmony between learning inside the classroom and outside the classroom. Therefore, involving instructors in implementing smartphones into the teaching and learning process and guiding learners towards the effective and appropriate use of their smart devices for English language learning is necessary.

Next, the research findings imply that the participants still tend to use their computers or laptops for practicing and enhancing language skills to a greater degree than the smart devices, and they do not think that their language learning is dependent on their smartphones. This finding reveals that laptops and computers are still more prevalent among EFL learners when compared to using smartphones for developing their English language proficiency.

Finally, 44.2\% of participants claim that they cannot imagine learning English without their smartphones, which suggests that although the learners might consider smartphones important, most of them do not seem to think that the smartphone occupies a crucial and decisive role concerning their language learning.

Table 1: General statements

\begin{tabular}{|c|c|c|c|c|c|c|}
\hline Statement & SA & A & $\mathbf{N}$ & D & SD & Mean \\
\hline $\begin{array}{l}\text { 1. The advent of smartphones has greatly contributed to my } \\
\text { language learning process. }\end{array}$ & $18.2 \%$ & $55.8 \%$ & $23.4 \%$ & $2.6 \%$ & $0 \%$ & 3.90 \\
\hline $\begin{array}{l}\text { 2. I cannot imagine learning English without my smartphone } \\
\text { anymore. }\end{array}$ & $9.1 \%$ & $35.1 \%$ & $26 \%$ & $28.6 \%$ & $1.3 \%$ & 3.22 \\
\hline $\begin{array}{l}\text { 3. Learning English through my smartphone represents an } \\
\text { innovative and effective way of learning a language. }\end{array}$ & $20.8 \%$ & $54.5 \%$ & $18.2 \%$ & $6.5 \%$ & $0 \%$ & 3.90 \\
\hline $\begin{array}{l}\text { 4. My smartphone enables me to practice and improve my English } \\
\text { whenever and wherever I want. }\end{array}$ & $40.3 \%$ & $53.2 \%$ & $5.2 \%$ & $1.3 \%$ & $0 \%$ & 4.32 \\
\hline $\begin{array}{l}\text { 5. I know how to plan my language learning through my } \\
\text { smartphone. }\end{array}$ & $3.9 \%$ & $44.2 \%$ & $42.8 \%$ & $9.1 \%$ & $0 \%$ & 3.43 \\
\hline $\begin{array}{l}\text { 6. I prefer using my smartphone to using a computer or a laptop } \\
\text { when it comes to practicing and improving my English. }\end{array}$ & $9.1 \%$ & $26 \%$ & $24.6 \%$ & $31.2 \%$ & $9.1 \%$ & 2.95 \\
\hline 7. My language learning success is dependent on my smartphone. & $3.9 \%$ & $6.5 \%$ & $24.6 \%$ & $49.4 \%$ & $15.6 \%$ & 2.34 \\
\hline $\begin{array}{l}\text { 8. Using my smartphone for the purposes of practicing and } \\
\text { improving my language learning skills makes me a more } \\
\text { autonomous learner. }\end{array}$ & $6.5 \%$ & $50.6 \%$ & $33.8 \%$ & $9.1 \%$ & $0 \%$ & 3.55 \\
\hline $\begin{array}{l}\text { 9. Smartphones create great opportunities for practicing and } \\
\text { improving my English. }\end{array}$ & $24.7 \%$ & $55.8 \%$ & $18.2 \%$ & $1.3 \%$ & $0 \%$ & 4.04 \\
\hline $\begin{array}{l}\text { 10. In the future, smartphones will form an inseparable part of } \\
\text { language learning process, both in the classroom as well as } \\
\text { outside the classroom. }\end{array}$ & $13 \%$ & $46.7 \%$ & $27.3 \%$ & $13 \%$ & $0 \%$ & 3.60 \\
\hline & \multicolumn{5}{|c|}{ Overall mean } & 3.52 \\
\hline
\end{tabular}

\subsection{Out-of-the-classroom statements}

Table 2 shows the students' responses to the out-of-the-classroom statements on smartphones. The subjects agree with most of the statements (16 out of 19), and their level of agreement is lower within the statements 7,13 , and 18. 
Overall, the participants assent to the following. They use smartphones for the purposes of learning English outside their English classes, and using the smartphones makes them more autonomous, saves their time, is convenient for them, helps them do their home assignments, and enables them to effectively share and exchange the course-related material with their peers. Nearly eight out of ten participants use smartphones for practicing English outside the classroom, which demonstrates that smartphones are commonly employed outside school, and that they seem to have assumed considerable importance within the learning process of EFL learners. Moreover, these smart devices are timesaving, helpful, and convenient for students. It should be also emphasized that smartphones create plenty of opportunity to share and exchange various files and materials among learners, which enables them to work on assignments and projects in pairs or groups, and they can consult and compare their answers and solutions to tasks and assignments.

Furthermore, $91 \%$ of the participants use smartphones outside the classroom to check and find out the meaning of unknown words, correct pronunciation (83\% of the participants), and appropriate grammatical structures (70\% of the participants). Employing smartphones outside their classes also helps learners develop reading ( $87 \%$ of the participants), listening (70\% of the participants), and writing skills ( $68 \%$ of the participants) and the systems of grammar (66\% of the participants), vocabulary ( $94 \%$ of the participants), and pronunciation ( $65 \%$ of the participants). The subjects have a dictionary app installed on their smartphones, and they use this application on a regular basis.

Therefore, the attitudes of students towards the use of smartphones with regard to the development of English language systems vary. Most subjects (94\%) think that the use of smartphones outside the classroom aids learners with improving their vocabulary, while approximately two thirds of participants believe that smartphones help them develop their grammar and pronunciation. Learning and enhancing EFL vocabulary (lexis being one of the most verified language system in relation to smartphones in the context of EFL learning) has been examined in numerous studies with promising results in which smartphones demonstrated potential for the development of lexical system of EFL learners (see, for example, Ebadi and Bashiri, 2018; Wu, 2014 or Lei, 2018).

In a similar way, the results reveal that the smartphone has a potential for practicing almost all the language skills, but to varying degrees. The students believe that, for example, the smartphone enables them to practice reading skills to a greater extent than listening skills. Further, the participants maintain that the language skills of reading, listening, and writing can be enhanced with the use of smartphones. However, they do not share this opinion when it comes to practicing speaking skills as only $36.4 \%$ of the students think that using their smartphones outside the classroom helps them improve their oral skills. This is an interesting piece of finding as the skill of speaking is often regarded as the primary language skill, which is often at the centre of attention for EFL learners (Mishan and Timmis, 2015; Ur, 2012). Increasing the awareness of practicing speaking skills through the smartphone (for example using a video chat with other peers) among the EFL learners would possibly stimulate their interest in developing speaking via smartphones. Although several papers attempted to investigate the development of speaking skills using smartphones (see, for example, Abugohar, Yunus and Rashid, 2019; Darmi and Albion, 2017; Sherine, Sastry and Seshagiri, 2020), exploring the enhancement of oral skills and subskills using smartphones is a matter that requires attention of teachers and researchers in the future studies.

Using a dictionary, EFL learners become more autonomous and take on some responsibility for their own learning. The smartphone makes this usage even easier as the students carry their smartphones with them all the time. They can check the vocabulary and other language aspects in their dictionary whenever and wherever they want. Thus, EFL learners are offered a considerable advantage when compared to computers or laptops, for example, as far as dictionary or other apps are concerned.

The overall mean was calculated at 3.86, which indicates that their attitudes to employing smartphones out of the classroom for the purposes of language learning are reasonably positive. However, approximately half of the subjects prefer using smartphones to using a computer for reading emails outside the classroom, while the other half is either neutral or disagrees with this statement.

It has been already mentioned that EFL learners can experience a number of benefits with the English language apps and it is, therefore, surprising that less than a half of the participants use various applications on their smartphones with regard to practicing their English outside the classroom. The reason for this possibly 
lies in the limited awareness of smartphone apps among Slovak EFL learners. The research findings demonstrate that despite the fact that most of the students agreed with the majority of statements, which demonstrates reasonably positive attitudes towards smartphones in the process of learning English, it should be noted that there are still some issues with smartphones in connection with EFL teaching and learning such as the limited use of apps for practicing English systems and skills or practicing speaking skills. These issues need to be the focus of researchers' attention in further studies.

Table 2: Outside-the-classroom statements

\begin{tabular}{|c|c|c|c|c|c|c|}
\hline Statement & SA & A & $\mathbf{N}$ & D & SD & Mean \\
\hline $\begin{array}{l}\text { I use my smartphone for the purposes of learning English } \\
\text { outside the English classroom. }\end{array}$ & $20.8 \%$ & $58.4 \%$ & $14.3 \%$ & $6.5 \%$ & $0 \%$ & 3.94 \\
\hline $\begin{array}{l}\text { Using smartphones for the purposes of learning English outside } \\
\text { the English classroom makes my language learning process more } \\
\text { autonomous. }\end{array}$ & $15.6 \%$ & $51.9 \%$ & $32.5 \%$ & $0 \%$ & $0 \%$ & 3.83 \\
\hline $\begin{array}{l}\text { Practicing my English via smartphone outside the English } \\
\text { classroom saves my time. }\end{array}$ & $18.2 \%$ & $45.4 \%$ & $32.5 \%$ & $3.9 \%$ & $0 \%$ & 3.78 \\
\hline $\begin{array}{l}\text { Practicing my English through my smartphone outside the } \\
\text { English classroom is convenient for me. }\end{array}$ & $19.5 \%$ & $53.2 \%$ & $24.7 \%$ & $2.6 \%$ & $0 \%$ & 3.90 \\
\hline $\begin{array}{l}\text { My smartphone helps me in doing my home assignments } \\
\text { outside the English classroom. }\end{array}$ & $23.4 \%$ & $49.3 \%$ & $14.3 \%$ & $11.7 \%$ & $1.3 \%$ & 3.82 \\
\hline $\begin{array}{l}\text { Using my smartphone, I can easily and effectively share and } \\
\text { exchange the course-related material with my peers. }\end{array}$ & $36.4 \%$ & $53.2 \%$ & $7.8 \%$ & $2.6 \%$ & $0 \%$ & 4.23 \\
\hline $\begin{array}{l}\text { I prefer using my smartphone to a computer or a laptop for the } \\
\text { purposes of reading and writing emails outside the classroom. }\end{array}$ & $22 \%$ & $27.3 \%$ & $22.1 \%$ & $22.1 \%$ & $6.5 \%$ & 3.36 \\
\hline $\begin{array}{l}\text { I use my smartphone outside the classroom in order to find } \\
\text { out/check the meaning of unknown words. }\end{array}$ & $63.6 \%$ & $27.3 \%$ & $5.2 \%$ & $2.6 \%$ & $1.3 \%$ & 4.49 \\
\hline $\begin{array}{l}\text { I use my smartphon } \\
\text { out/check the corre }\end{array}$ & $44.1 \%$ & $39 \%$ & $9.1 \%$ & $6.5 \%$ & $1.3 \%$ & 4.18 \\
\hline $\begin{array}{l}\text { I use my smartphone outside the English classroom in order to } \\
\text { find out/check the appropriate grammatical structures. }\end{array}$ & $28.6 \%$ & $41.5 \%$ & $20.8 \%$ & $7.8 \%$ & $1.3 \%$ & 3.88 \\
\hline $\begin{array}{l}\text { Using my smartphone outside the English classroom helps me } \\
\text { develop my listening skills. }\end{array}$ & $26 \%$ & $44.1 \%$ & $20.8 \%$ & $6.5 \%$ & $2.6 \%$ & 3.84 \\
\hline $\begin{array}{l}\text { Using my smartphone outside the English classroom helps me } \\
\text { develop my reading skills. }\end{array}$ & $29.9 \%$ & $57.1 \%$ & $7.8 \%$ & $5.2 \%$ & $0 \%$ & 4.12 \\
\hline $\begin{array}{l}\text { Using my smartphone outside the English classroom helps me } \\
\text { develop my speaking skills. }\end{array}$ & $9.1 \%$ & $27.3 \%$ & $41.5 \%$ & $16.9 \%$ & $5.2 \%$ & 3.18 \\
\hline $\begin{array}{l}\text { Using my smartphone outside the English classroom helps me } \\
\text { develop my writing skills. }\end{array}$ & $14.3 \%$ & $53.2 \%$ & $22.1 \%$ & $7.8 \%$ & $2.6 \%$ & 3.69 \\
\hline $\begin{array}{l}\text { Using my smartphone outside the English classroom helps me } \\
\text { develop my grammar. }\end{array}$ & $13 \%$ & $53.2 \%$ & $23.4 \%$ & $9.1 \%$ & $1.3 \%$ & 3.68 \\
\hline $\begin{array}{l}\text { Using my smartphone outside the English classroom helps me } \\
\text { develop my vocabulary. }\end{array}$ & $44.1 \%$ & $49.4 \%$ & $6.5 \%$ & $0 \%$ & $0 \%$ & 4.38 \\
\hline $\begin{array}{l}\text { Using my smartphone outside the English classroom helps me } \\
\text { develop my pronunciation. }\end{array}$ & $13 \%$ & $51.9 \%$ & $27.3 \%$ & $6.5 \%$ & $1.3 \%$ & 3.69 \\
\hline $\begin{array}{l}\text { I use various applications on my smartphone with regard to } \\
\text { practicing my English outside the English classroom. }\end{array}$ & $9.1 \%$ & $39 \%$ & $32.4 \%$ & $15.6 \%$ & $3.9 \%$ & 3.34 \\
\hline \multirow[t]{2}{*}{$\begin{array}{l}\text { I have a dictionary application installed on my smartphone and I } \\
\text { use this application regularly }\end{array}$} & $48 \%$ & $29.9 \%$ & $5.2 \%$ & $13 \%$ & $3.9 \%$ & 4.05 \\
\hline & \multicolumn{5}{|c|}{ Overall mean } & 3.86 \\
\hline
\end{tabular}




\section{Conclusion and recommendations}

In today's world, people are attaching increasing importance to smartphones, and apart from their widespread use for communication or socializing, they offer huge potential for enhancing the language learning process. Within this context and in order to fill the research gap in the Slovak area of learning English, the present study aimed to examine attitudes of Slovak EFL learners towards the use of smartphones within their English language learning.

Based on the first research question, which concerned general statements on the use of smartphones, it was established that the Slovak university EFL learners display moderately positive attitudes towards smartphones in the context of learning English as a foreign language. The participants of the study believe that smartphones allow them to practice their English language skills whenever and wherever they want (this enables them to liberate their language learning from the constraints of time and place), possibly in an innovative and effective way, contributing substantially to their learning process, and that they will form an inseparable part of their language learning process in the future. Furthermore, the findings indicate that learners may become more autonomous when they use their smartphones for the purposes of practicing and learning English. This can be considered a rather significant finding as students' autonomy is an important characteristic of a successful language learner, and EFL learners can take a certain amount of responsibility for their own learning.

However, there are also some difficulties EFL learners are confronted with. For instance, students believe that they face some issues within planning their language learning through smartphones, and they still do not think that their language learning is dependent on their smart devices. Involving teachers in the managerial and planning process, the learners ought to develop a design which would clearly set what is best learnt in the classroom, what outside the classroom, and how to make connections between the two concepts so that the learning process is effective and ultimately improved. Moreover, building awareness of the smartphone potential could also lead to the increase in their usage, making their language learning more dependent on their smart devices. It should be emphasized that it is also the EFL teachers who need to be concerned with developing the awareness of the implementation of smartphones into the teaching and learning process as they can guide their students towards the effective and appropriate use of these smart devices.

The second research question aimed to examine the attitudes of EFL learners towards the use of smartphones outside their English classrooms as plenty of foreign language acquisition takes place outside the school. In a similar way, the responses to these statements reveal that there exists a moderately positive attitude of the Slovak EFL learners towards smartphones. Apart from using them for practicing language skills and systems, EFL learners believe that they can also experience other considerable benefits; smartphones save their time, help them do their tasks and home assignments, they are useful for exchanging course-related materials with other peers, and they make them more autonomous and less teacher-dependent. These findings support the notion that employing smartphones both inside and outside the classroom may facilitate their language learning process and increase their success in learning English, which is conditioned by the proper use of smartphones and smartphone apps.

However, there are also some drawbacks that need to be overcome. Interestingly, less than $50 \%$ of the subjects uses various applications on their smartphone with regard to practicing their English outside the English classroom. Smartphone apps have numerous advantages EFL learners can benefit from, and it appears that the awareness of smartphone apps ought to be increased among the learners as well as teachers, highlighting the benefits English language students can enjoy. They have a vast number of smartphone apps at their disposal, but they ought to be able to carefully choose those apps and use them wisely, which might result in enhanced language learning. Conducting studies on the usage of English language learning apps by EFL students is of considerable importance and more studies are needed in this regard.

Another issue is that the participants do not think that using smartphones outside their classrooms helps them improve their speaking, a skill which is by many considered as the primary language skill. EFL learners need to understand that speaking can be practiced by means of smartphones in a number of ways, for example by using various chat protocols and video calls with their friends and classmates or by recording oneself, which is then followed by the speech analysis conducted by learners themselves or by their peers. Again, the awareness must be raised, and both students and teachers need to understand that speaking skills and subskills can be practiced and enhanced through smartphones and smartphone apps. 
The limitations of this study include some aspects of the chosen research sample. The study was carried out at only one of the universities in Slovakia which prepares prospective teachers of English. Thus, the findings report the current state of only one university, employing convenience sampling, which means that the results cannot be used to generalize the entire population. Including more universities with the same study programmes along with a larger research sample could prove useful and increase the validity of research. Moreover, employing more research methods such as the interview, observation, or testing would possibly reinforce the findings.

Exploring the attitudes of EFL learners to smartphones as well as the implementation of smartphones into the teaching and learning process seems promising, but there are several issues that demand attention of researchers and which need to be resolved. It is expected that his paper can serve as a guide to future studies in this field; the abovementioned findings could provide necessary impetus for further investigation into this area, especially in Slovakia where such examination is absent, and the research on this matter is still in its infancy. Exploring attitudes in more detail with the employment of other research methods, and investigating the effects of using smartphone in the context of EFL settings on particular language systems and skills would prove useful and help fill in the gap in the Slovak EFL teaching and learning by means of modern technologies. Moreover, comparing learners' attitudes to computers with the perceptions of smartphones or the efficiency between learning via smartphones and learning through computers and laptops would also prove important along with conducting studies in relation to smartphone applications and how they are used by EFL learners. Therefore, it is vital that further studies on using smartphones for the purposes of English language learning are performed.

\section{References}

Abugohar, M., Yunus, K. and Ab Rashid, R., 2019. Smartphone applications as a teaching technique for enhancing tertiary learners' speaking skills: perceptions and practices. International Journal of Emerging Technologies in Learning 14(9), pp. 74-92. https://doi.org/10.3991/ijet.v14i09.10375

Abdullah, N., Tajuddin, A. and Soon, G., 2019. Mandarin students' perceptions of smartphone applications in mandarin learning. Universal Journal of Educational Research 7(9A), pp.61-70. https://doi.org/10.13189/ujer.2019.071608

Abugohar, M., Yunus, K. and Rashid, A., 2019. Smartphone applications as a teaching technique for enhancing tertiary learners' speaking skills: perceptions and practices. International Journal of Emerging Technologies in Learning 14(9), pp.74-92. https://doi.org/10.3991/ijet.v14i09.10375

Aljaloud, A., Gromik, N., Kwan, P. and Billingsley, W., 2019. Saudi undergraduate students' perceptions of the use of smartphone clicker apps on learning performance. Australasian Journal of Educational Technology 35(1), pp.85-99. https://doi.org/10.14742/ajet.3340

Almunawar, M., Anshari, M., Susanto, H. and Chen, C., 2015. Revealing customer behavior on smartphones. International Journal of Asian Business and Information Management 6(2), pp.33-49. https://doi.org/10.4018/IJABIM.2015040103

Alzubi, A., 2019. Teachers' perceptions on using smartphones in teaching English as a foreign language. Research in Social Sciences and Technology (RESSAT) 4(1), pp.92-104, [online] Available at: <https://www.learntechlib.org/p/209835/> [Accessed 21 April 2020].

Alzubi, A. and Singh, M., 2017. The use of language learning strategies through smartphones in improving learner autonomy in EFL reading among undergraduates in Saudi Arabia. International Journal of English Linguistics 7(6), pp.59-72. http://doi.org/10.5539/ijel.v7n6p59

Ansarin, A., Farrokhi, F., Mahboudi, H. and Jam, Z., 2017. Attitudes towards smart phones and tablets. International Journal of Applied Linguistics \& English Literature 6(5), pp.66-82. http://dx.doi.org/10.7575/aiac.ijalel.v.6n.5p.66

Anshari, M., Almunawar, M., Shahrill, M., Wicaksono, D. and Huda, M., 2017. Smartphones usage in the classrooms: learning aid or interference? Education and Information Technologies, 22(6), pp.3063-3079. https://doi.org/10.1007/s10639-017-9572-7.

Balula, A., Marques, F. and Martins, C., 2015. Bet on top hat - challenges to improve language proficiency. Proceedings of EDULEARN15 Conference 6-8 July 2015, pp. 2627-2633). Spain: Barcelona.

Barrs, K., 2011. Mobility in learning: the feasibility of encouraging language learning on smartphones. Studies in Self-Access Learning Journal 2(3), pp.228-233.

Darmi, R. and Albion, P., 2017. Enhancing oral communication skills using mobile phones among undergraduate English language learners in Malaysia. In A. Murphy, H. Farley, L.E. Dyson and H. Jones (Eds.) Mobile Learning in Higher Education in the Asia-Pacific Region, pp.297-314. Singapore: Springer.

Ebadi, S. and Bashiri, S., 2018. Investigating EFL learners' perspectives on vocabulary learning experiences through smartphone applications. Teaching English with Technology, 18(3), 126-151, [online] Available at: <https://www.tewtjournal.org/issues/volume-18/volume-18-issue-3/> [Accessed 21 April 2020].

Hossain, M., 2018. Exploiting smartphones and apps for language learning: a case study with the EFL learners in a Bangladeshi university. Review of Public Administration Management 6(1). https://doi.org/10.4172/2315$\underline{7844.1000241 .}$. 
Ismail, I., Bokhare, S., Azizan, S. and Azman, N., 2013. Teaching via mobile phone: a case study on Malaysian teachers' technology acceptance and readiness. The Journal of Educators Online 10(1), pp.1-38.

Kandasamy, C. and Habil, H., 2018. Exploring cooperative learning method to enhance speaking skills among school students. LSP International Journal 5(2), 1-16. https://doi.org/10.11113/Ispi.v5n2.59

Kim, D., Chun, H. and Lee, H., 2014. Determining the factors that influence college students' adoption of smartphones. Journal of the Association for Information Science and Technology 65(3). https://doi.org/10.1002/asi.22987

Kim, D., Rueckert, D., Kim, D. and Seo, D., 2013. Students' perceptions and experiences of mobile learning. Language Learning \& Technology 17(3), pp.52-73, [online] Available at: $<$ https://scholarspace.manoa.hawaii.edu/bitstream/10125/44339/1/17 03 kimetal.pdf > [Accessed 21 April 2020].

Klímová, B., 2018. Mobile phones and/or smartphones and their apps for teaching English as a foreign language. Education and Information Technologies 23(3), pp.1091-1099. https://doi.org/10.1007/s10639-017-9655-5

Kafyulilo, A., 2014. Access, use and perceptions of teachers and students towards mobile phones as a tool for teaching and learning in Tanzania. Education and Information Technologies 19(1), pp.115-127. https://doi.org/10.1007/s10639$\underline{012-9207-y}$

Kukulska-Hulme, A., 2009. Will mobile learning change language learning? ReCALL 21(2), pp.157-165. https://doi.org/10.1017/S0958344009000202

Lei, Z., 2018. Vocabulary learning assisted with smart phone application. Theory and Practice in Language Studies 8(11), pp.1511-1516. http://dx.doi.org/10.17507/tpls.0811.17

Luo, B., Lin, Y., Chen, N. and Fang, W., 2015. Using smartphone to facilitate English communication and willingness to communicate in a communicate language teaching classroom. Proceedings of the 15th International conference on Advanced Learning Technologies, pp.320-322). IEEE.

Machmud, K., 2018. Using smartphone-integrated model of teaching to overcome students' speaking anxiety in learning English as a foreign Language. Journal of Arts \& Humanities 6(9), pp.1-11. http://dx.doi.org/10.18533/journal.v6i9.1249

Margaryan, A., Littlejohn, A.and Vojt, G., 2011. Are digital natives a myth or reality? University Students' Use of Digital Technologies. Computers \& Education 56, pp.429-440. https://doi.org/10.1016/j.compedu.2010.09.004

Metruk, R., 2019. The call of the MALL: the use of smartphones in higher education. A literature review. Revista Dilemas Contemporáneos: Educación, Política y Valores 6(3), pp.1-22, [online] Available at:<https://dilemascontemporaneoseducacionpoliticayvalores.com/ files/200004733ea787eb6e4/19.05.52\%20El\%20llamado\%20del\%2OMALL.\%20El\%20uso\%20de\%20los\%20tel\%C3\%A9fonos\%20intelig entes......pdf> [Accessed 21 April 2020].

Metruk, R., 2020. Confronting the challenges of MALL: distraction, cheating, and teacher readiness. International Journal of Emerging Technologies in Learning 15(2), pp.4-14. https://doi.org/10.3991/ijet.v15i02.11325

Mishan, F. and Timmis, I., 2015. Materials development for TESOL. Edinburgh: Edinburgh University Press Ltd.

Namaziandost, E., Shatalebi, V. and Nasri, M. 2019. The impact of cooperative learning on developing speaking ability and motivation toward learning English. Journal of Language and Education 5(3), pp.83-101. https://doi. org/10.17323/jle.2019.9809

Nikolajová-Kupferschmidtová, E., Štubňa, P. and Kučmová-Lenzi, A. 2018. Rebus linguae. On selected aspects of languages for special purposes. Uherské Hradiště: Vědecké nakladatelství Fakulty veřejnoprávních a ekonomických studií.

Ozdamli, F. and Uzunboylu, H. 2015. M-learning adequacy and perceptions of students and teachers in secondary schools. British Journal of Educational Technology 46(1), pp.159-172. https://doi.org/10.1111/bjet.12136

Rosell-Aguilar, F. (2014). How smartphone apps are revolutionising language learning. The conversation [online]. Available at:<https://theconversation.com/how-smartphone-apps-are-revolutionising-language-learning-25165> [Accessed 21 April 2020].

Rovithis, E., Floros, A., Moustakas, N., Vogklis, K. and Kotsira, L., 2019. Bridging audio and augmented reality towards a new generation of serious audio-only games. The Electronic Journal of e-Learning, 17(2), pp.144-156. https://doi.org/doi:10.34190/JEL.17.2.07

Şad, S. and Göktaş, Ö., 2014. Preservice teachers' perceptions about using mobile phones and laptops in education as mobile learning tools. British Journal of Educational Technology 45(4), pp. 606-618. https://doi.org/10.1111/bjet.12064

Sarhandi, P., Bajnaid, A. and Elyas, T., 2017. Impact of smartphone based activities on EFL students' engagement. English Language Teaching 10(6), pp. 103-117. http://doi.org/10.5539/elt.v10n6p103

Sherine, A., Sastry, M. and Seshagiri, A., 2020. Improving second language speaking and pronunciation through smartphones. International Journal of Interactive Mobile Technologies 14(11), pp.280-287. https://doi.org/10.3991/ijim.v14i11.13891

Statista. Smartphone users worldwide 2016 - 2021, [online] Available at<https://www.statista.com/statistics/330695/number-of-smartphone-users-worldwide/> [Accessed 25 October 2019].

Straková, Z. and Cimermanová, I., 2018. Developing reflective skills of student teachers in the virtual learning environment. Electronic Journal of e-Learning 16(2), pp.107-121 , [online] Available at $<$ https://issuu.com/academicconferences.org/docs/ejel-volume16-issue2-article646?mode=a p $>$ [Accessed 21 April 2020]. 
Štubňa, P., 2019. Simultaneous interpretation quality assessment. Revista Dilemas Contemporáneos: Educación, Política y Valores 6 - special issue, pp.1-15, [online] Available at $<$ http://files. dilemascontemporaneoseducacionpoliticayvalores.com/2000053924b89f4c865/EE\%2019.07.06\%20Evaluaci\%C3\%B3n\%20de\%20la\%20calidad\%20de\%20la\%20interpretaci\%C3\%B3n\%2 0simult\%C3\%A1nea.pdf> [Accessed 21 April 2020].

Tayan, B., 2017. Students and teachers' perceptions into the viability of mobile technology implementation to support language learning for first year business students in a middle eastern university. International Journal of Education \& Literacy Studies 5(2), pp.74-83. http://dx.doi.org/10.7575/aiac.ijels.v.5n.2p.74

Teodorescu, A. (2015). Mobile learning and its impact on business English learning. Procedia-Social and Behavioral Sciences, 180, 1535-1540. https://doi.org/10.1016/j.sbspro.2015.02.303

Theoharidou, M., Mylonas, A. and Gritzalis, D., 2012. A risk assessment method for smartphones. In D. Gritzalis, S. Furnell and M. Theoharidou (Eds.) Information Security and Privacy Research, pp.443-456. Heidelberg: Springer.

Ur, P., 2012. A course in English language teaching. Cambridge: Cambridge University Pres.

White, J. and Mills, D., 2014. Examining attitudes towards and usage of smartphone technology among Japanese university students studying EFL. CALL-EJ 15(2), pp.1-15, [online] Available at $<$ http://www.callej.org/journal/152/White Mills 2014.pdf> [Accessed 21 April 2020].

Wu, Q., 2014. Learning ESL vocabulary with smartphones. Procedia - Social and Behavioral Sciences 143, pp.302-307. https://doi.org/10.1016/j.sbspro.2014.07.409

Yaman, I., Şenel, M. and Yeşilel, D., 2015. Exploring the extent to which ELT students utilise smartphones for language learning purposes. South African Journal of Education 35(4), pp.1-9. http://dx.doi.org/10.15700/saje.v35n4a1198 